\title{
Preface
}

\section{An Amiable Collaboration}

The long involvement with this one place grew out of shared enthusiasms as much as personal absorption. Mario Navarrete Hernández, an archaeologist and Veracruzano, entered into the study with me. La Antigua is his home town; he helped me appreciate it and taught me a good deal about the prehistory and the history of the lowlands to the south of it. We poured water over each other's heads at the end of a day's excavation. When he was made director of the Museum of Anthropology in Xalapa and took his place on the national council overseeing archaeological projects, he was able to help our joint investigation of Prehispanic wetland agriculture through various bureaucratic thickets.

Groups of men from the villages of El Pando and Loma Iguana helped us in our fieldwork, commenting on their surroundings or the events of the day and recounting sometimes how things had been. The gringos, in turn, often amused them. I have thanked them personally long since, of course, but acknowledge their assistance here as a reminder of some of the most enjoyable aspects of fieldwork.

This project could not have been carried out if Ing. Carlos Soza Lagunes and Don Francisco González had not graciously allowed us repeatedly to perforate their pastures.

Arturo Gómez-Pompa, when he directed the Instituto Nacional de Investigación sobre Recursos Bióticos, showed warm personal interest and provided most agreeable contexts for the early discussion of the possibilities for the investigation of Prehispanic wetland agriculture in Central Veracruz. He activated a key contact in a federal ministry for the release of materials on the San Juan Basin. Various members of the institute participated in the investigation; Manuel G. Zolá Báez was often in the field with us and contributed valuable botanical and microtopographic materials. 
Alastair Robertson, who should have been a co-author, was drawn even further than I into the San Juan Basin's detail. I value his work with air photographs, the large-scale maps of the agricultural remains that he prepared, and his determined search through repositories of governmental materials, but most of all his close environmental observations. I see him still, on his motorcycle, trailing exhaust, with some new measuring device of his own fabrication tied to the rear carrier. He shared the passion, took endless pains, and on occasion held up a mirror.

Julie Stein, archaeologist at the University of Washington in Seattle, taught me about coring. She did not need to come into the field for this; she did it in periodic "tutorials" in her office and meanwhile published basic essays on the subject. Dolores Piperno of the Smithsonian Tropical Research Institute helped us a great deal by interpreting the phytoliths in our samples.

Richard Hebda, paleoecologist at the Royal Museum of British Columbia in Victoria, and adjunct professor at the University of Victoria, made time repeatedly to come into the field. He led us all in the interpretation of the natural context of our Prehispanic materials and the planning of the processing of the various diagnostic remains, but that is too fibrous a way of putting it. He was, he is, always positive, energetic, and often entertainingly expansive.

I thank Richard's wife Elaine for her forbearance, and my wife Alice, not only for her forbearance but her active support at many junctures.

A variety of grants, from the Social Science and Humanities Research Council of Canada, the National Geographic Society, and the Humanities and Social Sciences Committee at the University of British Columbia, helped to sustain us.

A number of Mexican discussants lent me their perspectives: Juan Pablo Martínez Davila, instructor at the Colegio de Postgraduados, Campus Veracruz, helped me to understand the midtwentieth-century reports of the engineers of the Secretaría de Recursos Hidráulicos (SRH) regarding the San Juan Basin. I was fortunate to spend time with various of his colleagues too, particularly Carlos Olguín Palacios and Octavio Ruiz Rosado. The still sprightly Ing. Adolfo Orive Alba, minister of SRH during the presidency of Miguel Alemán, when the major hydraulic intervention in the Basin was undertaken, shared some fine background political information and most interesting historical photographs. Ana Lid del Angel Pérez, investigator at the Instituto Nacional de Investigaciones Forestales y Agropecuarias, Campo Cotaxtla, Vera- 
cruz, was free with the results of her inquiry into animal husbandry on the eastern side of the Basin.

Andrew Sluyter, geographer at the University of Texas at Austin and then at Pennsylvania State, has long agreed with me that Central Veracruz is the center of the world. He obtained a fine long core out of the central lake of the San Juan Basin and thus provided paleoecological context and finer meshed elaboration of our introductory efforts. He mastered not only the materials of prehistory but also those of history; he facilitated many specific aspects of my own historical research. His doctoral dissertation on the ecological restructuring of Central Veracruz after the Encounter is state of the art-and the polemic.

Alba González Jácome, anthropologist and historian at the Universidad Iberoamericana in Mexico City, facilitated our work with contacts, advice, and criticism - all from a solid base of scholarly integrity and good sense, and often enough with pointed repartee.

Tonatiuh Romero, graduate student at the Universidad Iberoamericana (IBERO) and archival adept, guided me through the Archivo General de la Nación in the Palacio Lecumberri, the old prison straight out of the eighteenth-century plans of Jeremy Bentham; we would begin in the central rotunda and go down one or another of the spokes of the great wheel into the relevant sections of materials accommodated in former cells.

I was able to ventilate the techniques and concepts of the whole long inquiry into Prehispanic wetland agriculture in various graduate seminars at IBERO. I came to appreciate the students very much; they were kind enough to repeatedly declare themselves interested, even enthusiastic.

There were other forums, notably the meetings of the Scientific Committee on Problems of the Environment (SCOPE) in Seville, in January of $\mathrm{I} 992$, focused on the environmental impact of the Encounter. Such an inquiry is strongly indicated for Central Veracruz and the Mexican Gulf Coast, of course, but the results cannot be as sweeping or dramatic as they appear to be in some other areas of Latin America. In the preparation of an edited volume in honor of my good friend Phil Wagner, I was able to sketch out my idea for the treatment of the Basin (Siemens I992). Odile Hoffmann invited me to a lively symposium on the social organization and representation of space at the Centro de Investigaciones y Estudios Superiores en Antropología Social, Región Golfo, at Xalapa, Veracruz, in September of 1994; I was able to test out some of Foucault's ideas in Central Veracruz. 
David Skerritt Gardner, a historian at the Universidad Veracruzana and intimately familiar with matters agrarian in Central Veracruz, invited me to a seminar on regional processes, but also repeatedly met me for coffee at La Parroquia in Xalapa. He tempered and supplemented many of my historical observations, indeed he took the trouble to read an early version of this analysis and made very good suggestions. I am grateful also to William Doolittle, geographer at the University of Texas at Austin, for his encouragement of this project and his reading of the manuscript. Other encouragement came out of Austin: Shannon Davies has been a gracious, facilitating editor. She managed to sound surprised at one point that the final version would be ready so soon. Various of her colleagues helped this very imprecise author with the minutia of copyediting.

From the beginning of this project I followed a chimera: computerized wizardry would somehow allow me to do marvelous things, like making vertical photographs out of obliques and converting the San Juan Basin into dramatic topography that could be tilted, rotated, and inscribed with any number of distributions. I was defeated on both counts, always just ahead or just behind the necessary technology, dogged by incompatible map bases or software versions. I came to appreciate a fine Mexican expression: "sí, pero no"-yes it can be done, but unfortunately not. Catherine Griffith helped me get what was feasible and is the main architect of the maps and diagrams; Daniel Millette assisted at several critical cartographic junctures, as did Elaine Cho, Solomon Wong, and Doug Brown. Maija Heimo and Klaudia Zapala amiably helped to tame the text. 